\title{
UTILIZATION OF POLYCLONAL ANTIBODIES PRODUCED IN LOCAL HORSES (EQUUS CABALLUS) AS A RESOURCE FOR DEVELOPMENT OF ELISA CONJUGATE TO DETECT HEPATITIS B VIRUS (HBV) SURFACE ANTIGENS
}

\author{
S. N. Depamede, M. Sriasih and E. Yulianti \\ Faculty of Animal Science, Mataram University, \\ Jl. Majapahit No. 62 Mataram NTB 83125 - Indonesia \\ Corresponding E-mail: sulaiman_n@unram.ac.id \\ Received April 20, 2012; Accepted May 26, 2012
}

\begin{abstract}
ABSTRAK
Tujuan dari penelitian ini adalah memanfaatkan antibodi poliklonal yang diproduksi dari kuda (Equus caballus) lokal Indonesia untuk membuat konjugat kit ELISA pendeteksi antigen permukaan virus hepatitis B (VHB; HBsAg). Antibodi poliklonal yang digunakan adalah dari kuda lokal yang diimunisasi berulang menggunakan HBsAg isolat Indonesia. Antibodi kemudian dikonjugasikan dengan enzim horseradish peroxidase dengan metode yang dimodifikasi dari Nakane dan Kawaoi. Uji aktivitas konjugat dilakukan dengan prinsip uji ELISA yang dikerjakan oleh peneliti dan juga oleh laboratorium independen. Sebagai pembanding, digunakan konjugat ELISA HBsAg komersial. Hasil penelitian ini menunjukkan bahwa antibodi yang diproduksi dari kuda lokal dapat digunakan untuk membuat konjugat dengan hasil yang sebanding dengan kit ELISA HBsAg komersial

Kata kunci: Kuda lokal, ELISA, antibodi poliklonal, hepatitis B, HBsAg
\end{abstract}

\begin{abstract}
The aim of this study was to utilize the antibody produced using Indonesia local horses (Equus caballus) to make the conjugate of ELISA kit for detection of hepatitis B virus (HBV) surface antigen (HBsAg). The polyclonal antibodies were isolated and purified from local horses immunized repeatedly using isolated and purified HBsAg from Indonesia. The antibodies were conjugated with horseradish peroxidase by a modified method of Nakane and Kawaoi. The conjugate activities were performed using the principle of ELISA test conducted by the researchers as well as by independent laboratory. Commercial conjugate for HBsAg ELISA was used as a comparison study. The results of this study indicated that the antibody produced from local horses can be used to make conjugates that were comparable to commercial HBsAg ELISA kit.
\end{abstract}

Keywords: Local equine, ELISA, polyclonal antibody, hepatitis B, HBsAg

\section{INTRODUCTION}

Up to now the hepatitis B virus (HBV) remains a major cause of world health problems as a cause of significant morbidity and mortality (Zukerman and Zukerman, 2000). Around the world, over 350 million people are infected chronically with HBV, some of them will develop severe liver disease including cirrhosis and hepatocellular carcinoma (Mulyanto et al., 2011, 2012). The highest prevalence of HBV infection is generally found in Asia and Africa (Lee, 1997). In Indonesia the prevalence of $\mathrm{HBV}$ varies among the islands. It has been reported that HBV carrier rates among apparently healthy populations range from 4 to 20.3\% (Khan et al., 2004; Mulyanto et al., 2008). Several efforts to prevent the spread of HBV have been conducted by the Indonesian government, such as through a national vaccination program of children and do the screening of blood donors carried out by the Indonesian Red Cross.

To perform the screening test, some standard test kits or methods such as enzyme-linked immunosorbent assay (ELISA) are required. Several standard test kits including ELISA are available in Indonesia. However, they mostly use components that are imported from overseas which may lead to elevated production cost. To anticipate the growing need, as well as to reduce our dependency on imported products, it is necessary to develop an ELISA kit against HBV 
with raw materials produced locally.

Horse (Equus caballus) has long been used for immunological research (Markel, 2007; Simon, 2007). However in Indonesia the utilization of local horses for diagnostic purposes is still limited. In this paper the results of the utilization of local horses as a source of polyclonal antibodies against $\mathrm{HBV}$, which were then used as raw materials to develop an ELISA conjugate, are reported. It is expected that the conjugate can be used for the development of ELISA kit for screening test of suspected samples being infected with HBV.

\section{MATERIALS AND METHODS}

\section{Chemicals and Equipment}

The enzyme horseradish peroxidase (HRP) Type VI-A (Lot No. 118 K 76701), ethylene glycol anhydrous $99.8 \%$ (Lot No. 0856AM), 1fluoro-2,4 dinitrobenzene (FDNB; Lot No. 0001451175), sodium meta-periodate (NaIO4; Lot No. MKBCB727), 3,3,',55-Tetramethylbenzidine (TMB) Substrate (T4444 \#089K1699), tween 20, BSA, were purchased from Sigma, USA, and sodium borohydride $\left(\mathrm{NaBH}_{4}\right)$ obtained from Merck. Other chemicals such as $\mathrm{NaCl}, \mathrm{KH}_{2} \mathrm{PO}_{4}$, were of analytical grade.

ELISA plates used were Microtiterwells, 12x8 (break apart) strips, 96 wells (SLP). Optical density measurements were made on a Thermo Scientific Multiscan EX Type 355 spectrophotometer (Shanghai, China).

\section{Polyclonal and Monoclonal Antibodies}

Anti HBV polyclonal antibody is produced locally (West Nusa Tenggara Hepatitis, WNTH Laboratory). It was derived from hyperimmune sera of adult local Equus caballus (Sumba and Lombok female horses) which multi- immunized with hepatitis B surface antigens (HBsAg) according to Mulyanto (1991). The polyclonal antibody was a gift from Prof. Mulyanto and used as the main material to develop the conjugate. The monoclonal antibody (WNTH Laboratory Lot No. KO436) which is anti "a" determinant specific to HBsAg was also a courtesy of Prof. Mulyanto. The antibody was used for coating the ELISA plates.

\section{ELISA Kit Commercial}

ELISA Kit commercial used as a 'gold' standard throughout this study was Wantai
HBsAg ELISA Kit (Wantai, China).

\section{Conjugate Preparation}

Conjugate was prepared for three days continuously by coupling HRP-aldehyde solution with horse-anti HBsAg polyclonal antibody based on Nakane and Kawaoi (1974) with slight modifications. On day one, HRP-aldehyde solution was prepared by dissolving a $5 \mathrm{mg}$ of HRP into $1.0 \mathrm{ml}$ freshly made of $0.3 \mathrm{M}$ sodium bicarbonate, $\mathrm{pH} 8.1$. In to this solution, $0.1 \mathrm{ml}$ of FDNB (1-fluoro-2,4-dinitrobenzene) in absolute ethanol was added, and then mixed gently for $1 \mathrm{hr}$ at room temperature. Subsequently $1.0 \mathrm{ml}$ of $0.08 \mathrm{M} \mathrm{NaIO}_{4}$ was added and mixed gently for $30 \mathrm{~min}$ at room temperature. Following this, $1.0 \mathrm{ml}$ of $0.16 \mathrm{M}$ ethylene glycol was added, mixed gently for $1 \mathrm{hr}$ at room temperature, and dialyzed against three 1-liter changes of $0.01 \mathrm{M}$ sodium carbonate buffer, $\mathrm{pH} 9.5$, at $4^{\circ} \mathrm{C}$.

After the dialysis, a $5 \mathrm{mg}$ of horse anti HBsAg-IgG was added to $3 \mathrm{~mL}$ of HRP-aldehyde solution and mixed gently for $3 \mathrm{hr}$ at room temperature. After that, $5 \mathrm{mg}$ of $\mathrm{NaBH}_{4}$ was added and let stand for $3 \mathrm{hr}$ at room temperature, then dialyzed at $4^{\circ} \mathrm{C}$ against PBS overnight.

Finally, the solution was purified by applying the solution to a $60 \times 1.5 \mathrm{~cm}$ Sephacryl200 HR column (Pharmacia, Sweden) equilibrated in PBS and the absorbance of the fractions was read at $280 \mathrm{~nm}$. The main peak fractions was pooled and designated as HRP labeled horse-anti HBsAg IgG polyclonal antibody and used for conjugate of the in-house HBsAg ELISA.

\section{ELISA Plates Preparation}

ELISA plates were prepared by a standard procedure by coating the wells with $5 \mu \mathrm{g} / \mathrm{mL}$ of mouse-anti HBsAg monoclonal antibody in carbonate buffer $\mathrm{pH} 9.5$ at $100 \mu \mathrm{L}$ per well and left overnight at $4^{\circ} \mathrm{C}$. Afterward, plates were blocked with $1 \%$ BSA-PBS, $300 \mu \mathrm{L} /$ well for $3 \mathrm{~h}$ at room temperature and washed 3 times with PBS containing $0.05 \%$ Tween 20 (PBS-T). Following washing, plates were dried and kept in a foil sachet with desiccate gel. The plates were stored in $4^{\circ} \mathrm{C}$ until used.

\section{Conjugate Tests}

The principle of conjugate test that had been developed from horse serum in this study was based on immunological reactions between the primary antibody coated to the plate and the antigen in the sample, and then the reaction to the 
conjugate. To that end, $50 \mu \mathrm{L}$ of three different (low, medium, and high) concentrations of inhouse HBsAg positive or negative standards were added into each well of plates coated with the primary antibody. Furthermore into the respective wells were added $50 \mu \mathrm{L}$ of conjugate. The plate was then sealed and incubated for $60 \mathrm{~min}$ at $37^{\circ} \mathrm{C}$. After incubation, the plate was washed with a washing solution of $300 \mu \mathrm{L}$ per well. Washing was performed 5 times, and $50 \mu \mathrm{L}$ of TMB substrate was added into each well subsequently. Following incubation for $15 \mathrm{~min}$ in a dark room at $37^{\circ} \mathrm{C}$, the reaction was stopped by adding $50 \mu \mathrm{L}$ of $1 \mathrm{~N}$ sulfuric acid into the respective wells. The reaction was then read using an ELISA photoreader at a $450 \mathrm{~nm}$ wavelength. Comparisons are performed simultaneously using a commercial ELISA Kit HBsAg. In addition, comparative test was also conducted by an independent laboratory with a commercial kit using a known concentration of HBsAg standard to obtain as objective result as possible. The HBsAg concentrations used were 0, 1.24, 5.43, 24.10, 107 and $465 \mathrm{IU} / \mathrm{mL}$.

\section{Data Analysis}

The data obtained were compared descriptively to give an idea of the quality of conjugated antibody produced in this study. Quantitative data regarding the ELISA tests were tabulated and analyzed according to Drouet et al. (2003), and Depamede and Kisworo (2011).

\section{RESULTS AND DISCUSSION}

Based on historical records, the horse has long been used for research in the field of immunology. Even since scientists have not been able to discover about the antigen-antibody reactions, Emil von Behring had successfully used horse serum as a serum therapy for diphtheria (Stiehm and Johnston, 2005; Raju, 2006, Simon, 2007). Nowadays horses still been used for serum therapy purposes (Bunning et al., 2002; de Cuetos et al., 2011), and for diagnostic development such as diagnostic for HBsAg. In this study the purified polyclonal antibody produced in local horses using $\mathrm{HBsAg}$ of Indonesia origin (Mulyanto, 1991) was used to make conjugates for $\mathrm{HBsAg}$ ELISA. Preparation of the conjugates includes several steps such as binding of HRP enzyme as a marker onto the polyclonal antibodies. Following the binding, the conjugate was purified by means of size-exlusion column method. In the present study the binding and purification methods were performed by using the classical method according to Nakane and Kawaoi (1974) with some modifications, and a representative result is presented in Figure 1. The main peak (fractions from minute 55 to minute 75 ) is the image of the binding reaction between the antibody and the HRP enzyme. The pooled fractions was then defined as the in-house conjugate and used in subsequent experiments.

To find out whether the developed conjugates could be used as a reagent to detect HBsAg, the conjugates were tested against a negative and three defined in-house positive standard samples. The test results are shown in Figure 2. It can be seen in Figure 2 that the conjugates produced in this study gave comparable results to existing commercial kits ( $\mathrm{P}$ $>0.05)$. Furthermore, test results carried out by an anonymous independent laboratory (Figure 3 ) was also revealed that the conjugates produced in this study have a comparable quality to that of the commercial conjugate against known concentration of HBsAg standards used to perform the comparison tests. Pattern of curves presented in Figures 2 and 3 are in agreement with the results of Karakus et al. (2007).

According to Gerritse et al. (1991), key points to consider when developing a conjugate is process itself should not affect the activity of enzymes and antibodies used. The results of the present study indicated that the conjugate (pooled fractions of the main peak, Figure 1) provides immunological and enzymatic reactions that are

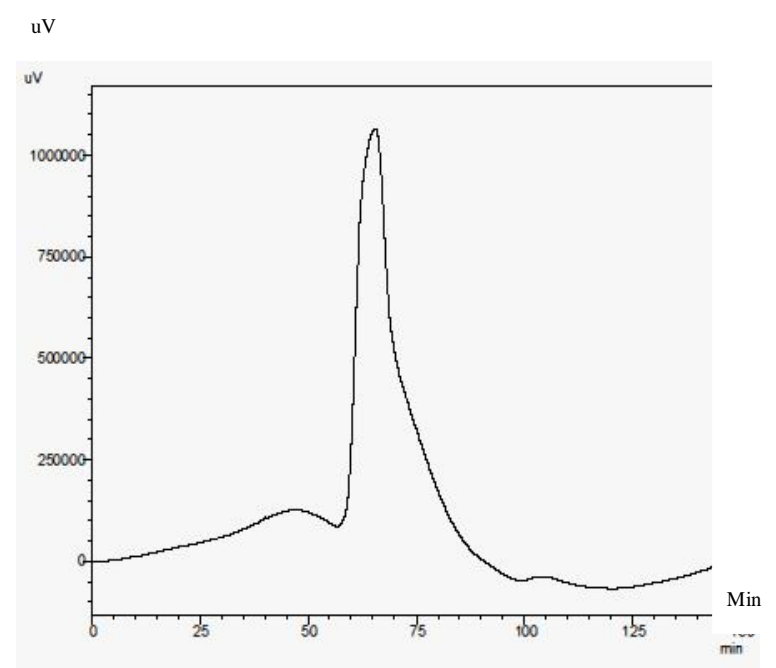

Figure 1. Representation of Chromatogram of $5 \mathrm{mg}$ Horse Anti HBsAg IgG Conjugated with $5 \mathrm{mg}$ HRP Activated by $0.08 \mathrm{M} \mathrm{NaIO} 4$ as Modified from Nakane and Kawaoi (1974) 


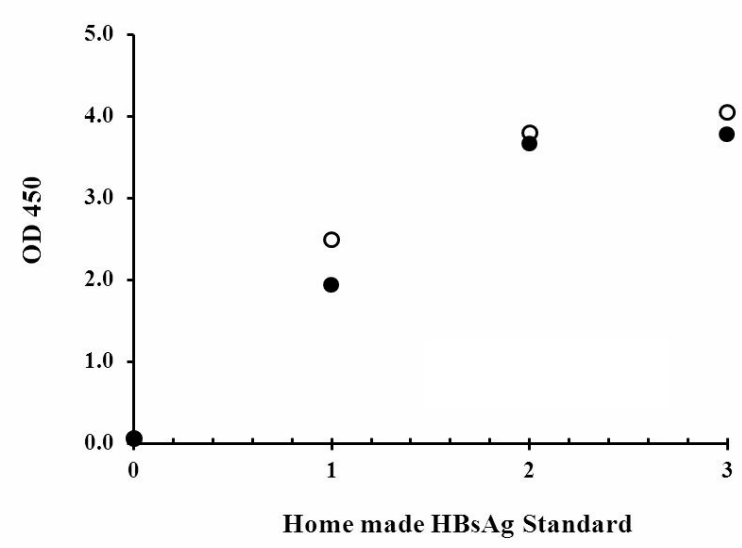

Figure 2. Comparison between Conjugate of this Study (•:LH) and a Commercial Conjugate (o: Wantai) against Various Concentration of Homemade (in-house) HBsAg Standards

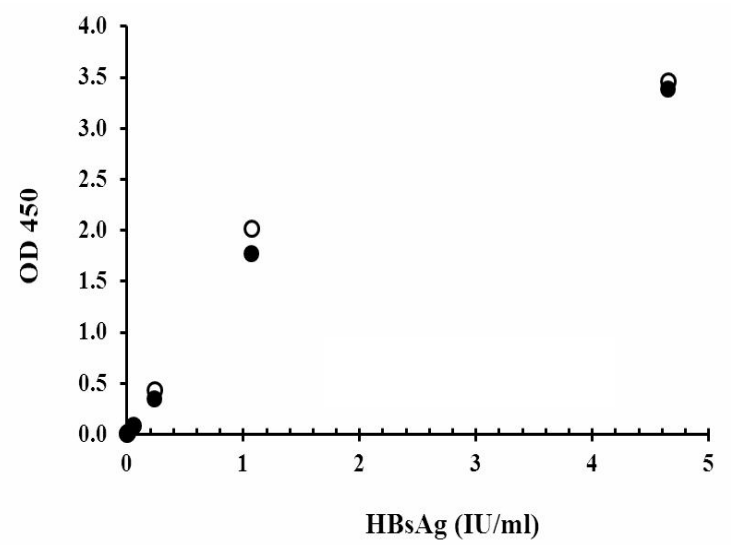

Figure 3. Comparison between Conjugate of this study $(\bullet: \mathrm{LH})$ and Anonymous Conjugate (o:Anonym) against Various Concentration $(0,1.24$, $5.43,24.10,107$ and $465 \mathrm{IU} / \mathrm{ml}$ ) of $\mathrm{HBsAg}$ Standards, Conducted by an Independent Laboratory

equivalent to a similar reaction on a commercial conjugate (Figure 2). Furthermore, the independent test results as shown in Figure 3 reinforced that the conjugates produced in this study gave reliable results. Even so, when it was seen in Figures 2 and 3 there was a tendency that the conjugates produced in this study (filled circles) was still below the commercial conjugate (open circles). Shin and Heo (2000) asserted that in addition to sensitivity and specificity of a diagnostic kit, the other values that need to also consider is detection limit and its reproducibility. For those reasons, the results of the present study still need to be followed up further.

Overall these results suggest that the antibodies produced by utilizing the local horses to develop the conjugate ELISA, can provide comparable results to conjugates that available commercially.

Utilization of Indonesia germ plasma is very important, especially in the efforts to develop vaccines and immunodiagnostics such as against $\mathrm{HBV}$, especially to improve the immune specificity of the vaccine or the kit. Recently it has been reported that in Indonesia some new HBV genotypes have been elucidated (Lusida et al., 2008, Mulyanto et al., 2009, 2010, 2011, 2012). This means that efforts to prevent the spread of HBV in Indonesia will be more effective if we can provide the components to develop diagnostic kits derives from the local germ plasma. This should become a serious concern for Indonesia with a population of more than 200 million people with the HBV carrier rates are 4-20.3\% (Khan et al., 2004; Mulyanto et al., 2008).

\section{CONCLUSION}

This study shows that antibody generated using the local horses can be utilized to develop test kit against infectious diseases such as Hepatitis B with feasible results. However, further studies are still required to improve it sensitivity, specificity, reproducibility and stability as needed by a diagnostic kit.

\section{ACKNOWLEDGMENTS}

The authors wish to thank Prof. Mulyanto, Director of West Nusa Tenggara (WNT) Hepatitis Laboratory-Indonesia, for his supports especially for the antibodies and reagents used throughout this study. The authors also thanks Mr. Hulaimi of WNT Hepatitis Laboratory, and Mr. Suparman, staff at the Immunobiology Laboratory of Faculty of Mathematics and Natural Sciences, Mataram University, for their technical assistances.

\section{REFERENCES}

Bunning, M.L., R.A. Bowen, C.B. Cropp, K.G. Sullivan, B.S. Davis, N. Komar, M.S. Godsey, D. Baker, D.L. Hettler, D.A. Holmes, B.J. Biggerstaff, and C.J. Mitchell. 2002. Experimental infection of horses with West Nile virus. Emerging infectious diseases. 8(4): 380-386. 
de Cuetos, E.E.V., R.A. Fernandez, M.I. Bianco, O.J. Sartori, M.L. Piovano, C. Lúquez, and L.I.T. de Jong. 2011. Equine botulinum antitoxin for the treatment of infant botulism. Clin. Vaccine Immunol. 18(11):1845-1849

Depamede, S.N. and D. Kisworo. 2011. Development of enzyme-linkage immunosorbent assay against type B of Clostridium botulinum: A preliminary study. J.Indonesian Trop.Anim.Agric. 36(4):237-242

Drouet, C., M-F. Nissou, D. Ponard, J. Arvieux, C. Dumestre-Perard, P. Gaudin, B. Imbert, C. Massot and F. Sarrot-Reynauld. 2003. Detection of anti endothelial cell antibodies by an enzyme-linked immunosorbent assay using antigens from cell lysate: Minimal interference with antinuclear antibodies and rheumatoid factors. Clin. Diagn. Lab. Immunol. 10:934939

Gerritse, K., M. Fasbender, W. Boersma and E. Claassen. 1991. Conjugate formation in urea: coupling of insoluble peptides to alkaline phosphatase for ELISA and in situ detection of antibody-forming cells. J. Histochem. Cytochem. 39(7):987-992

Karakus, R., L.A. Aral, B. Basturk and C. Abay. 2007. Development of a Highly Sensitive ELISA for Quantification of Hepatitis B Virus (HBV) Surface Antigen (HBsAg). Turkey J. Medical Sci. 37(2): 87-92

Khan, M., J.J. Dong, S.K. Acharya, Y. Dhagwahdorj, Z. Abbas, S.M.W. Jafri, D.H. Mulyono, N. Tozun and S.K. Sarin. 2004. Hepatology issues in Asia: Perspectives from regional leaders. J. Gastroenterology and Hepatology. 19:S419-S430

Lee, W.M., 1997. Hepatitis B virus infection. N. Engl. J. Med. 337 (24): 1733-1745

Lusida, M.I., V.E. Nugrahaputra, Soetjipto, R. Handajani, M. Nagano-Fujii, M., Sasayama, T. Utsumi and H. Hotta. 2008. Novel subgenotypes of hepatitis B virus genotypes C and D in Papua, Indonesia. J. Clin. Microbiol. 46(7):2160-2166

Markel, H. 2007. Long Ago Against Diphtheria, the Heroes Were Horses. The New York Times, July $2007 . \quad$ http://www.nytimes. com/2007/07/10/health/10hors.html?_r=1

Mulyanto, K. Surayah, S.N. Depamede, I.A. Lestarini, W. Budianto, Hafiludin, K. Umi, F. Tsuda, M. Takahashi and H, Okamoto. 2008. Hepatitis B virus infection in Eastern part of Indonesia. Abstract, Book of the Second
China-Indonesia Joint International Symposium on Hepatobiliary Medicine and Surgery, Chongqing, China.

Mulyanto, P. Pancawardani, S.N. Depamede, A. Wahyono, S. Jirintai, S. Nagashima, M. Takahashi, T. Nishizawa and H. Okamoto. 2012. Identification of four novel subgenotypes (C13-C16) and two inter-genotypic recombinants $(\mathrm{C} 12 / \mathrm{G}$ and $\mathrm{C} 13 / \mathrm{B} 3)$ of hepatitis $\mathrm{B}$ virus in Papua Province, Indonesia. Virus Res. 163: 129-140

Mulyanto, S.N. Depamede, A. Wahyono, Jirintai, S. Nagashima, M. Takahashi and H. Okamoto. 2011. Analysis of the full-length genomes of novel hepatitis B virus subgenotypes C11 and C12 in Papua, Indonesia. J. Med. Virol. 83(1): 54-64

Mulyanto, S.N. Depamede, K. Surayah, A.A. Tjahyono, Jirintai, S. Nagashima, M. Takahashi and H. Okamoto. 2010. Identification and characterization of novel hepatitis B virus subgenotype C10 in Nusa Tenggara, Indonesia. Arch. Virol. 155(5):705715

Mulyanto, S.N. Depamede, K. Surayah, F. Tsuda, K. Ichiyama, M. Takahashi, H. Okamoto. 2009. A nationwide molecular epidemiological study on hepatitis B virus in Indonesia: identification of two novel subgenotypes, B8 and C7. Arch. Virol. 154 (7):1047-1059.

Mulyanto. 1991. Perbedaan Imunogenisitas Hepatitis B surface antigen (HBsAg) dari berbagai Subtipe, Studi Seroepidemiologik dan Laboratorik dalam rangka Pemurnian HBsAg. Dissertation. Fakultas Pasca Sarjana. Universitas Airlangga. Indonesia.

Nakane, P.L., and A. Kawaoi. 1974. Peroxidaselabeled antibody a new method of conjugation.

J. Histo. Chem. 22(12):1084-1091

Shin, H-S., and T-R. Heo. 2000. Evaluation of rapid immunochromatographic assay kit for HBsAg-screening using whole blood. Biotechnol. Bioprocess Eng. 5: 362-365.

Simon, J. 2007. Emil Behring's medical culture: From disinfection to serotherapy. Medical History 51:201-218

Stiehm, E.R., and R.B. Johnston. 2005. A history of pediatric immunology. Pediatric Research 57: 458-467.

Zuckerman, J.N. and A.J. Zuckerman. 2000. Current topics in hepatitis B. J Infect. 41:130136. 